\title{
PENEGAKKAN HUKUM SANKSI PIDANA PERPAJAKAN BERDASARKAN UNDANG-UNDANG NOMOR 16 TAHUN 2019 TENTANG KETENTUAN UMUM DAN TATA CARA PERPAPAJAKAN DIKAITKAN DENGAN ASAS ULTIMUM REMEDIUM
}

\author{
oleh : \\ Agus Puji Priyono \\ Antonia Intarti
}

\begin{abstract}
ABSTRAK
Hukum pidana pajak dalam doktrin hukum pidana disebut sebagai ius singulare karena memiliki norma dan sanksi tersendiri. Orientasi utama pajak adalah pada pendapatan negara untuk meingkatkan kesejahteraan masyarakat sehingga fungsi sanksi pidana perpajakan merupakan alat pencegah (preventif) agar pelaku tindak pidana perpajakan tidak melanggar norma perpajakan. Namun demikian dalam penegakkan hukumnya tidak adanya parameter yang jelas dalam perumusan sanksi pidana perpajakan serta pemahaman dan tafsir asas ultimum remedium yang tidak sama. Untuk itu penelitian ini bertujuan menguraikan rumusan sanksi pidana perpajakan berdasarkan asas legalitas (certainty) dan selanjutnya penerapan asas ultimum remedium atas pidana tersebut berdasarkan asas efficiency tanpa mengesampingkan asas rasionalitas dan proporsionalitas (equality). Hasil dari penelitian ini menyimpulkan 2 (dua) hal. Pertama, Rumusan saksi administrasi dan sanksi pidana sebagai dasar penerapan asas ultimum remedium dalam tindak pidana perpajakan sesuai Undang-Undang Ketentuan Umum dan Tata Cara Perpajakan belum berfungsi sesuai dengan tujuannya yaitu menumbuhkan kesadaran Wajib Pajak untuk mematuhi kewajiban perpajakan karena proses penegakkan hukum pada tahap formulasi (kebijakan legislatif) belum memiliki kepastian hukum yang berkeadilan sehingga terdapat kebebasan interpretasi/penafsiran para penegak hukum dengan diskresi bebas (tidak terikat) yang berdampak pada tahap aplikasi (yudikatif) dan tahap eksekusi. Kedua, Penerapan asas ultimum remedium tidak diatur dalam satu bab atau pasal di Undang-Undang Ketentuan Umum dan Tata Cara Perpajakan sehingga harus dilakukan penafsiran sistematis dalam menafsirkan suatu ketentuan kata-kata dalam suatu peraturan dalam hubungannya dengan kalimat yang bersangkutan serta seluruh pasal dalam UndangUndang Ketentuan Umum dan Tata Cara Perpajakan harus dianggap sebagai suatu kesatuan sistem integral terkait, terpadu, dan saling dukung agar tidak menimbulkan perbedaan persepsi dan pemahaman dalam penerapannya
\end{abstract}

Keywords: Law Enforcement-Tax Crime-Ultimum Remedium

\section{PENDAHULUAN}

\section{A. Latar Belakang}

Pajak sebagai sumber utama pendapatan negara untuk membiayai pembangunan nasional dalam praktiknya banyak terjadi pelanggaran hukum di bidang perpajakan oleh para Wajib Pajak (selanjutnya ditulis WP) berupa kealpaan (culpa) maupun kesengajaan (dolus) untuk tidak menyetorkan pajak ke kas negara sehingga terjadi kerugian terhadap penerimaan negara yang mengakibatkan negara tidak mampu memberikan kesejahteraan 
kepada rakyat. Tegaknya prinsip self assessment system pada sistem perpajakan Indonesia untuk meningkatkan kepatuhan sukarela (tax compliance) dari WP sangat dibutuhkan adanya penegakkan hukum perpajakan (tax law enforcement) meliputi pemeriksaan pajak (tax audit), penyidikan pajak (tax investigation), dan penagihan pajak (tax collection).

Menurut Eddy O.S. Hiarej menyatakan bahwa aparat penegak hukum termasuk hakim yang memutus perkara, baik pada peradilan pajak maupun peradilan umum carut marut karena tidak adanya parameter yang jelas dalam menegakkan hukum pajak, mana yang merupakan perkara administrasi dan mana yang merupakan tindak pidana. ${ }^{1)}$ Adrianto Dwi Nugroho berpendapat serupa bahwa Undang-Undang KUP belum memberikan kepastian hukum mengenai perbuatan-perbuatan WP yang mana saja yang akan dikenakan sanksi administrasi dan yang akan dikenakan sanksi pidana. ${ }^{2}$ Politik hukum pidana dalam pemidanaan terhadap pelaku tindak pidana perpajakan di Indonesia berorientasi pada pendapatan negara sehingga sanksi pidana dan pemidanaan dibutuhkan. Sanksi pidana dan pemidanaan tersebut merupakan jaminan bahwa ketentuan peraturan perundang-undangan perpajakan akan dipatuhi. Dengan kata lain, sanksi pidana perpajakan merupakan alat pencegah (preventif) agar pelaku tindak pidana perpajakan tidak melanggar norma perpajakan. ${ }^{3)}$

Dalam praktik penegakkan hukum untuk meningkatkan kepatuhan berkembang berbagai pemahaman dan tafsir ultimum remedium seperti WP yang dikenai pidana tidak dapat dikenai upaya administrasi SKPKB, pemahaman ultimum remedium sebagai upaya terakhir yang harus didahului oleh proses administrasi secara bertahap dan runtut, pemeriksaan bukti permulaan bukan sebagai bagian dari proses awal penyidikan Hal ini dapat dipahami karena secara eksplisit bahasa undang-undang yang mengatur hubungan antar ketentuan pengaturan hal-hal yang beririsan, saling terkait, dan berurutan dirumuskan kurang gamblang. ${ }^{4)}$

\section{B. Rumusan Masalah}

1. Bagaimanakah rumusan ketentuan sanksi pidana perpajakan yang diatur dalam Undang-Undang Ketentuan Umum dan Tata Cara Perpajakan?

2. Bagaimanakah penerapan ultimum remedium tindak pidana perpajakan yang diatur dalam Undang-Undang Ketentuan Umum dan Tata Cara Perpajakan?

\section{TINJAUAN PUSTAKA}

\section{A. Tinjauan Penegakkan Hukum}

Soerjono Soekanto menjelaskan bahwa setidaknya ada beberapa masalah yang berasal dari undang-undang yang bisa menimbulkan gangguan terhadap penegakkan hukum, yaitu tidak diikutinya asas-asas berlakunya undang-undang, belum adanya peraturan pelaksana yang digunakan untuk menerapkan Undang-undang, dan ketidak

1) Eddy O.S Hiariej, "Penegakkan Hukum Pidana Pajak:Ultimum Remedium ataukah Primum Remedium?", Seminar Ultimum Remedium : Dari Sisi Hukum Pidana dan Hukum Administrasi Negara, Yogyakarta, 2018, hlm. 1

2) Adrianto Dwi Nugroho, Hukum Pidana Pajak Indonesia, Citra Aditya Bakti, Bandung, 2010, hlm. 23

3) Simon Nahak, Hukum Pidana Perpajakan, Setara Press, Malang, 2014, hlm. 34

4) Gunadi, op.cit, hlm. 1 
jelasan arti kata-kata dalam Undang-undang yang akan berakibat kesimpangsiuran dalam penafsiran serta penerapannya. ${ }^{5}$

Menurut Barda Nawawi Arif menegakkan hukum pidana harus melalui beberapa tahap yang dilihat sebagai usaha atau proses rasional yang sengaja direncanakan untuk mencapai suatu tertentu yang merupakan suatu jalinan mata rantai aktifitas yang tidak termasuk bersumber dari nilai-nilai dan bermuara pada pidana dan pemidanaan. Tahaptahap tersebut ${ }^{6}$ adalah tahap formulasi, tahap Aplikasi, tahap eksekusi.

Menurut Muchsan pelaksanaan diskresi oleh aparat pemerintah (eksekutif) dibatasi oleh 4 (empat) hal ${ }^{7)}$, yaitu apabila terjadi kekosongan hukum, adanya kebebasan interprestasi/penafsiran, adanya delegasi perundang-undangan, dan demi pemenuhan kepentingan umum

Penanggulangan kejahatan empirik terdiri dari tiga bagian pokok $^{8}$, yaitu pre-emtif (penangkalan/pencegahan secara dini), preventif (pengendalian/pengawasan), dan represif (penindakan).

\section{B. Tinjauan Penemuan Hukum dan Penafsiran Hukum Pajak}

Beberapa pakar hukum memberikan gambaran jelas mengenai penemuan hukum ${ }^{9)}$ adalah sebagai berikut:

1. Van Eikema Hommes menyatakan bahwa penemuan hukum lazimnya diartikan sebagai proses pembentukan hukum oleh hakim atau petugas hukum lainnya yang diberi tugas melaksanakan hukum terhadap peristiwa-peristiwa konkret.

2. Paul Scholten menyatakan bahwa penemuan hukum adalah sesuatu yang lain daripada hanya penerapan peraturan-peraturan pada peristiwanya. Kadang-kadang dan bahkan sering terjadi peraturannya harus ditemukan baik dengan jalan intervensi maupun dengan jalan analogi ataupun rechtsvervijning.

Soedjono berpendapat bahwa penafsiran hukum atau interpretasi adalah menentukan arti atau makna suatu teks atau bunyi suatu pasal berdasar pada kaitannya. ${ }^{10)}$ Manfaat penafsiran kegunaan hukum pajak salah satunya dalam menetapkan kepastian yang berupa sanksi administrasi ataupun sanksi tata usaha, sanksi pidana berupa penjara ataupun kurungan. ${ }^{11}$

Ada beberapa metode penafsiran menurut ilmu hukum yang digunakan dalam menafsirkan hukum pajak menurut Susi Zulvina ${ }^{12)}$, yaitu sebagai berikut penafsiran Tata Bahasa atau Gramatikal (Taalkundig), penafsiran Otentik, penafsiran Sistematik, penafsiran Historis, penafsiran Sosilogis (Teleologis), dan penafsiran Doktriner.

5) Soerjono Soekanto, "Faktor-Faktor yang Mempengaruhi Penegakkan Hukum”, Pidato Pengukuhan dalam Jabatan Guru Besar Tetap pada Fakultas Hukum Universitas Indonesia, Jakarta, 1983, hlm. 2

6) Barda Nawawi Arief, Teori-teori dan Kebijakan Pidana, Alumni, Bandung, 1984, hlm. 173

7) Muchsan, Beberapa Catatan Tentang Hukum Administrasi Negara Dan Peradilan Administrasi Negara Di Indonesia, Liberty, Yogyakarta, 1981, hlm. 3

8) Dedy Nor Ardiyanto,"Tinjauan Kriminologis Penyalahgunaan Dextromethorpham (DMP) oleh Remaja di Kabupaten Jepara (Studi Kasus di Polres Jepara)", Jurisprudence, Vol. 4 No. 1, Universitas Muhammadiyah Surakarta, 2014, hlm.41-42

9) Zaeni Asyhadie dan Arief Rahman, Pengantar Ilmu Hukum, Jakarta, Raja Grafindo Persada, 2013, hlm. 165-166

10) Soedjono Dirdjosisworo, Pengantar Ilmu Hukum, Jakarta, Raja Grafindo Persada, 2008, hlm. 157

11) Fadhil, "Penafsiran Hukum Pajak", http://aspirasipajak.blogspot.com, diakses 30 Juni 2019 , pkl. 18.00 WIB

12) Susi Zulvina, Pengantar Hukum Pajak, Jakarta, STAN, 2011, hlm. 43-46 


\section{Tinjauan Tujuan dan Maksud Pidana Perpajakan}

Tujuan hukum pidana sebenarnya mengandung makna pencegahan terhadap gejalagejala sosial yang kurang sehat di samping pengobatan bagi yang telah terlanjur berbuat tidak baik untuk mengatur dan membatasi tingkah laku manusia dalam meniadakan pelanggaran kepentingan umum. ${ }^{13-}$

Barda Nawawi Arief berpendapat bahwa tujuan dari kebijakan pemidanaan yaitu menetapkan suatu pidana tidak terlepas dari tujuan politik kriminal yaitu perlindungan masyarakat untuk mencapai kesejahteraan sehingga untuk menjawab dan mengetahui tujuan serta fungsi pemidanaan, maka tidak terlepas dari teori-teori tentang pemidanaan yang ada. ${ }^{14)}$

Indonesia menganut model kepatuhan WP yang dirumuskan oleh The Organisation for Economic Co-operation and Development (OECD) Centre for Tax Policy and Administration. Berdasarkan model tersebut dapat diketahui bahwa perilaku kepatuhan WP bervariasi dan dibagi menjadi 4 (empat) tingkat dengan 4 (empat) jenis strategi kepatuhan yang dapat dilakukan oleh otoritas pajak. Pada tingkatan yang paling baik/ideal adalah saat WP sudah memiliki kesadaran yang sangat tinggi dalam melaksanakan kewajiban perpajakannya (willing to do the right things), sehingga strategi kepatuhannya fiskus harus terus menerus memberikan kemudahan dan pelayanan yang terbaik. Secara lengkap tingkat kepatuhan disajikan dalam tabel berikut: ${ }^{15)}$

\section{Tinjauan Asas-Asas Pidana Perpajakan}

Asas adalah kebenaran yang menjadi tumpuan berpikir atau berpendapat. Selain itu juga berarti alas atau landasan, alas berarti bukti untuk menguatkan suatu keterangan. ${ }^{16}$ ) Satjipto Rahardjo mengemukakan bahwa asas hukum merupakan jiwanya norma hukum atau peraturan hukum karena merupakan dasar lahirnya peraturan hukum (ratio legis-nya) peraturan hukum. ${ }^{17)}$

Pendapat Mardjono Reksodiputro dalam Mardjono Reksodiputro ${ }^{18)}$ ada sejumlah asas yang patut diperhatikan untuk menentukan bagaimana hukum pidana dirumuskan dan diselenggarakan, yakni asas rasionalitas, asas toleransi terhadap perbuatan, asas subsidiaritas, asas proporsionalitas, asas legalitas, dan asas Praktis dan Efektifitasnya.

Ultimum remedium, merupakan salah satu asas yang terdapat di dalam hukum pidana Indonesia yang menyatakan bahwa hukum pidana haruslah ditempatkan sebagai upaya terakhir/senjata pamungkas dalam hal penegakkan hukum pidana setelah pendekatan-pendekatan non penal lain tidak berhasil untuk dilakukan. Sudikno Mertokusumo dalam bukunya mengartikan bahwa ultimum remedium sebagai alat terakhir. ${ }^{19)}$ Hal tersebut menjadi dasar pertimbangan Mahkamah Agung dalam Putusan Mahkamah Agung Nomor 01/Pdt./G./2010/PN. Bgl bahwa peranan hukum pidana

13- Ibid, hlm.157

14) Barda Nawarwi Arif, op.cit., hlm. 33

15) Simanjuntak dan Mukhlis, Dimensi Ekonomi Perpajakan dalam Pembangunan Ekonomi, Raih Asa Sukses (RAS), Jakarta, 2012, hlm.86-89

16) Mohammad Daud Ali, Hukum Islam, Pengantar Ilmu Hukum dan Tata Hukum Islam di Indonesia, Raja Grafindo, Jakarta, 2001, hlm. 114

17) Satjipto Rahardjo, Ilmu Hukum, Alumni, Bandung, 1985, hlm. 85

18) Mardjono Reksodiputro, "Hak Asasi Manusia Dalam Sistem Peradilan Pidana”, Pusat Pelayanan Keadilan dan Pengabdian Hukum (d/h Lembaga Kriminologi), Universitas Indonesia, Jakarta, 1994, hlm. 84

19) Chandra Khoirunnas, "Penerapan Primum Remedium terhadap Hukuman Mati Bagi Terpidana Narkoba”, http://ckhoirunnas.blogspot.co.id, diakses 31 Desember 2016, pkl.17.21 WIB 
memerlukan pintu terakhir (exit clause) sesuai asasnya yaitu sebagai ultimum remedium, artinya peran dan fungsi hukum pidana sebagai sarana obat terakhir, apabila cara-cara lain tidak bisa terpenuhi.

Pengenaan sanksi tindak pidana perpajakan seharusnya diidentikan dengan ultimum remedium dari suatu tax fraud/tax evasion (pengemplangan/penggelapan pajak) agar dapat menimbulkan deterrent effect bagi setiap pelanggaran pidana pajak, sekaligus juga untuk memberikan kepastian hukum dalam tindak pidana mengingat dasar adanya tindak pidana adalah asas legalitas dan dasar dapat dipidananya pembuat adalah asas kesalahan dan mengingat penghitungan kerugian (pada pendapatan) negara, yang setidak-tidaknya mendekati kebenaran materiil. ${ }^{20)}$

Adam Smith dalam bukunya Wealth of Nations dengan ajaran yang terkenal The Four Maxims dikutip Waluyo ${ }^{21}$, asas pemungutan pajak asas equality (asas keseimbangan dengan kemampuan atau asas keadilan), asas certainty (asas kepastian hukum), asas convinience of Payment (asas pemungutan pajak yang tepat waktu atau asas kesenangan), da asas efficiency (asas efisien atau asas ekonomis).

\section{E. Tinjauan Tindak Pidana Perpajakan}

Memori penjelasan Pasal 33 ayat (3) Undang-Undang Penanaman Modal menjelaskan bahwa yang dimaksud dengan tindak pidana perpajakan adalah

"Informasi yang tidak benar mengenai laporan yang terkait dengan pemungutan pajak dengan menyampaikan surat pemberitahuan,tetapi yang isinya tidak benar atau tidak lengkap atau melampirkan keterangan yang tidak benar sehingga dapat menimbulkan kerugian pada negara dan kejahatan lain yang diatur dalam undangundang yang mengatur perpajakan.”

\begin{tabular}{|c|c|c|c|}
\hline No & Kesalahan & Sanksi Administrasi & Sanksi Pidana \\
\hline (1) & $\begin{array}{l}\text { Tidak mendaftarkan diri } \\
\text { untuk diberikan NPWP } \\
\text { atau dikukuhkan PKP }\end{array}$ & $\begin{array}{l}\text { NPWP/PKP Jabatan } \\
\text { (Ps. } 2 \text { (4) UU 9/1994) } \\
\text { Sanksi Bunga SKPKB } \\
\text { (Ps. 13 (1) huruf e UU } \\
\text { 28/2007) }\end{array}$ & $\begin{array}{l}\text { Pidana penjara dan } \\
\text { denda } \\
\text { (Ps. 39 (1) huruf a UU } \\
\text { 6/1983) }\end{array}$ \\
\hline (2) & Tidak menyampaikan SPT & $\begin{array}{l}\text { Surat Teguran } \\
\text { (Ps } 3 \text { (5a) UU 16/2000) } \\
\text { Sanksi Denda STP (Ps } 7 \text { UU } \\
\text { 16/2000) } \\
\text { Sanksi Kenaikan SKPKB } \\
\text { (Ps. 13 (1) huruf b UU } \\
6 / 1983) \\
\text { Sanksi Kenaikan SKPKB } \\
\text { (alpa ke-1) } \\
\text { (Ps 13A UU 28/2007) }\end{array}$ & $\begin{array}{l}\text { Pidana } \\
\text { kurungan/penjara dan } \\
\text { denda Ps } 38 \text { huruf a \& } \\
\text { Ps } 39 \text { (1) huruf c UU } \\
6 / 1983\end{array}$ \\
\hline
\end{tabular}

20) Henry D.P. Sinaga dan Benny R.P. Sinaga, Rekonstruksi Modep-Model Pertanggung jawaban di Bidang Perpajakan dan Kepabeanan, Kanisius, Yogyakarta, 2018, hlm. 149

21) Waluyo, Perpajakan Indonesia, Salemba Empat, Jakarta, 2010, hlm. 43 


\begin{tabular}{|c|c|c|c|}
\hline (3) & $\begin{array}{l}\text { Menyampaikan } \\
\text { SPT/keterangan } \\
\text { benar/tidak lengkap }\end{array}$ & $\begin{array}{l}\text { Sanksi Bunga/Kenaikan } \\
\text { SKPKB } \\
\text { (Ps 13 (1) huruf huruf (a) \& } \\
\text { (c) UU 6/1983) } \\
\text { Sanksi Kenaikan SKPKB } \\
\text { (alpa ke-1) } \\
\text { (Ps 13A UU 28/2007) }\end{array}$ & $\begin{array}{l}\text { Pidana } \\
\text { kurungan/penjara dan } \\
\text { denda Ps } 38 \text { huruf b \& } \\
\text { Ps } 39 \text { (1) huruf d UU } \\
6 / 1983\end{array}$ \\
\hline (4) & $\begin{array}{l}\text { Tidak menyelenggarakan / } \\
\text { memperlihatkan } \\
\text { pembukuan / pencatatan }\end{array}$ & \multirow{2}{*}{$\begin{array}{l}\text { Ditetapkan penghasilan } \\
\text { secara jabatan } \\
\text { (UU 6/1983) } \\
\text { Sanksi Kenaikan SKPKB } \\
\text { (Ps 13 (1) huruf (d) UU } \\
\text { 6/1983) }\end{array}$} & $\begin{array}{l}\text { Pidana penjara dan } \\
\text { denda Ps } 39 \text { (1) huruf } \\
\text { g UU 6/1983 }\end{array}$ \\
\hline (5) & $\begin{array}{l}\text { Tidak menyimpan buku, } \\
\text { catatan, atau dokumen } \\
\text { yang menjadi dasar } \\
\text { pembukuan }\end{array}$ & & $\begin{array}{l}\text { Pidana penjara dan } \\
\text { denda Ps } 39 \text { (1) huruf } \\
\text { h UU 6/1983 }\end{array}$ \\
\hline (6) & $\begin{array}{lr}\text { Tidak menyetorkan } & \text { pajak } \\
\text { yang } & \text { telah } \\
\text { dipotong/dipungut } & \\
\end{array}$ & \multirow{3}{*}{$\begin{array}{l}\text { Sanksi } \text { Bunga } / \text { Kenaikan } \\
\text { SKPKB } \\
\begin{array}{lllll}\text { Ps 13 } & \text { (a) dan } & \text { (c) } & \text { UU } \\
6 / 1983) & & & & \end{array}\end{array}$} & $\begin{array}{l}\text { Pidana penjara dan } \\
\text { denda Ps } 39 \text { (1) huruf I } \\
\text { UU 6/1983 }\end{array}$ \\
\hline (7) & $\begin{array}{l}\text { Memperlihatkan } \\
\text { pembukuan / dokumen } \\
\text { palsu }\end{array}$ & & $\begin{array}{l}\text { Pidana penjara dan } \\
\text { denda Ps } 39 \text { (1) huruf } \mathrm{f} \\
\text { UU 6/1983 }\end{array}$ \\
\hline (8) & $\begin{array}{l}\text { Menyalahgunakan atau } \\
\text { menggunakan tanpa hak } \\
\text { NPWP atau Pengukuhan } \\
\text { PKP }\end{array}$ & & $\begin{array}{l}\text { Pidana penjara dan } \\
\text { denda } \\
\text { (Ps. } 39 \text { (1) huruf b UU } \\
\text { 6/1983) }\end{array}$ \\
\hline (9) & $\begin{array}{ll}\text { Menolak dilakukan } \\
\text { pemeriksaan }\end{array}$ & $\begin{array}{l}\text { Ditetapkan penghasilan } \\
\text { secara jabatan (UU 9/1994) } \\
\text { Sanksi Kenaikan SKPKB } \\
\text { (Ps 13 (1) huruf (d) UU } \\
\text { 28/2007) }\end{array}$ & $\begin{array}{l}\text { Pidana penjara dan } \\
\text { denda Ps } 39 \text { (1) huruf } \\
\text { e UU 16/2000 }\end{array}$ \\
\hline (10) & $\begin{array}{l}\text { Menerbitkan dan / atau } \\
\text { menggunakan faktur pajak, } \\
\text { bukti pemungutan pajak, } \\
\text { bukti pemotongan pajak, } \\
\text { dan / atau bukti setoran } \\
\text { pajak yang tidak } \\
\text { berdasarkan transaksi yang } \\
\text { sebenarnya }\end{array}$ & \multirow[t]{2}{*}{$\begin{array}{l}\text { Sanksi } \text { Bunga } \text { /Kenaikan } \\
\text { SKPKB } \\
\begin{array}{lllll}\text { Ps 13 } & \text { (a) dan } & \text { (c) } & \text { UU } \\
6 / 1983) & & & & \end{array}\end{array}$} & $\begin{array}{l}\text { Pidana penjara dan } \\
\text { denda } \\
\text { (Ps. 39A huruf a UU } \\
\text { 28/2007) }\end{array}$ \\
\hline (11) & $\begin{array}{l}\text { Menerbitkan faktur pajak } \\
\text { tetapi belum dikukuhkan } \\
\text { sebagai Pengusaha Kena } \\
\text { Pajak }\end{array}$ & & $\begin{array}{l}\text { Pidana penjara dan } \\
\text { denda } \\
\text { (Ps. 39A huruf b UU } \\
\text { 28/2007) }\end{array}$ \\
\hline
\end{tabular}

Bentuk-bentuk opzet atau kesengajaan secara umum oleh Van Hamel dibagi menjadi 3 (tiga) yaitu: ${ }^{22}$ kesengajaan sebagai maksud atau tujuan (Opzet als oogmerk), kesengajaan sebagai kesadaran akan kepastian (Opzet met bewustheid of

22) P.A.F. Lamintang, Dasar-Dasar Hukum Pidana Indonesia, Citra Aditya Bakti, Bandung, 2013, 
noodzakelijkheid), kesengajaan dengan kesadaran akan kemungkinan (Opset bij mogelijkheidsbewustzijn).

John Salmond memiliki pendapat sebagaimana dikutip Henri Sinaga bahwa pertanggungjawaban pidana yang tujuan utamanya untuk menghukum pelaku pelangggaran sehingga tolok ukurnya adalah persamaan di hadapan hukum dan sebagai upaya akhir, di mana pertimbangan harus mengacu pada 3 (tiga) hal yaitu motif pelanggaran, tingkat/besarnya pelanggaran, dan karakter pelaku pelanggaran. ${ }^{23)}$

\section{F. Tinjauan Ketentuan Sanksi Perpajakan dalam Undang-Undang KUP}

a) Kesalahan perpajakan yang dilakukan oleh Wajib Pajak dalam ketentuan UndangUndang KUP telah diatur dalam Bab yang berurutan dari administrasi ke pidana sejak tahun 1983 hingga 2009 sebagai berikut Bab III yang mengatur tentang Penetapan dan Ketetapan pada Pasal 13, Pasal 14, Bab VIII yang mengatur tentang Ketentuan Pidana pada Pasal 38, Pasal 39, dan Bab VIII yang menambah pasal baru pada Pasal 13A dan Pasal 39A

\section{G. Tinjauan Ketentuan Ultimum Remedium dalam Undang-Undang KUP}

Brotodihardjo menyatakan secara kontekstual, dalam menafsirkan suatu ketentuan kata-kata dalam suatu peraturan harus ditafsirkan dalam hubungannya dengan kalimat yang bersangkutan atau penafsiran sistematis. Hal serupa juga disampaikan Gunadi bahwa seluruh pasal dalam UU KUP harus dianggap sebagai suatu kesatuan sistem integral terkait, terpadu, saling dukung perkuat membentuk satu kepastian hukum yang adil bagi semua WP dengan tetap lindungi hak fiskal negara. ${ }^{24)}$ Pasal-pasal yang mengandung asas ultimum remedium di dalam Undang-Undang KUP sebagai berikut Bab III yang mengatur tentang Penetapan dan Ketetapan pada Pasal 8 dan Bab VIII yang mengatur tentang Ketentuan Pidana pada Pasal 13A dan Pasal 44B ayat (2).

\section{PEMBAHASAN}

\section{A. Rumusan Sanksi Pidana dalam Undang-Undang KUP}

Permasalahan pada tingkat penindakan secara represif tingkat pertama yaitu pemeriksaan administrasi. Penulis sependapat dengan pernyataan Eddy O.S. Hiarej yang menyebutkan bahwa penegakkan hukum pajak tidak memiliki parameter yang jelas mana yang merupakan perkara administrasi dan tindak pidana. Penulis ambil contoh adalah kasus pidana perpajakan pada Bab III yang diputus oleh hakim di Pengadilan Negeri Palembang Nomor 394/Pid.Sus/2015.PN Plg yang memutuskan bebas karena terbukti tidak melaporkan SPT dengan benar. Pertimbangan hakim memutuskan bebas karena kesalahan yang dilakukan oleh Wajib Pajak tersebut dianggap merupakan kesalahan administrasi sehingga dapat dilakukan penegakkan hukum secara administrasi dengan diterbitkan Surat Ketetapan Pajak Kurang Bayar dan ditambah sanksi administrasi. Jadi tidak perlu dilakukan penegakkan hukum hingga sanksi pidana. Namun hal tersebut berbeda dalam kasus pidana perpajakan yang diputus oleh hakim di Pengadilan Negeri Sleman Nomor 544/Pid.Sus/2014/PN.Smn yang memvonis WP bersalah dan menjatuhkan sanksi pidana penjara dan denda karena terbukti secarasah dan meyakinkan WP telah melakukan tindak pidana perpajakan tidak lapor SPT dengan benar dan penegakkan hukum kepada Wajib Pajak dianggap sudah tidak dapat diupayakan secara administrasi.

\footnotetext{
23) Henry D.P. Sinaga \& Benny R.P. Sinaga, op.cit, hlm. 67

24) Gunadi, loc.cit
} 
Perumusan sanksi pidana harus mempertimbangkan nilai, asas, dan norma hukum agar tujuan dari hukum tersebut tercapai. Dalam pemidanaan nilai masyarakat yang harus diprioritaskan adalah melindungi masyarakat serta memajukan kesejahteraan umum dengan tetap memperhatikan hakekat dari tujuan hukum yaitu kepastian dan keadilan atau certainty dan equality.

Sesuai Undang-Undang KUP penegak hukum diberikan opsi atau pilihan untuk menerapkan sanksi administrasi maupun sanksi pidana sesuai kewenangan yang dimilikinya dalam menindak setiap kesalahan WP yang terdapat di Pasal 39 UU KUP sedangkan sanksi administrasi seharusnya hanya terbatas pada WP tertentu yang disebabkan oleh ketidakbenaran dalam pengisian SPT atau karena ditemukannya data fiskal yang tidak dilaporkan oleh Wajib Pajak. Namun pengertian WP tertentu tidak diberikan penjelasan lebih lanjut oleh Undang-Undang atau peraturan pelaksanaan. Hal inilah yang menyebabkan penegakkan hukum tidak jelas disebabkan karena ketidakbenaran pengisian SPT dapat dikenakan sanksi administrasi atau sanksi pidana.

Dalam merumuskan sanksi pidana, asas yang menjadi prioritas sebelum diterapkannya asas ultimum remedium adalah asas rasionalitas dan asas proporsionalitas disamping selanjutnya mempertimbangkan asas legalitas dan praktis serta efektifitasnya. Untuk itu berdasarkan rumusan penentuan kesalahan WP dalam Undang-Undang KUP penulis mencoba merumuskan sanksi administrasi maupun sanksi pidana sebagai berikut:

1. Penerapan kesalahan administrasi murni

Berdasarkan ketentuan dalam Pasal 14 UU KUP, sudah tepat kesalahan WP cukup dikenakan sanksi administrasi saja dengan diterbitkan Surat Tagihan Pajak (selanjutnya ditulis STP) karena sifat kesalahannya adalah minor, human error, prosedural/formil, dan tidak ada niat/karakter jahat seperti:

a. Pajak Penghasilan dalam tahun berjalan tidak atau kurang dibayar;

b. Dari hasil penelitian terdapat kekurangan pembayaran pajak sebagai akibat salah tulis dan/atau salah hitung;

c. WP dikenai sanksi administrasi berupa denda dan/atau bunga;

d. Pengusaha yang telah dikukuhkan sebagai Pengusaha Kena Pajak, tetapi tidak membuat faktur pajak atau membuat faktur pajak, tetapi tidak tepat waktu;

e. Pengusaha yang telah dikukuhkan sebagai Pengusaha Kena Pajak yang tidak mengisi faktur pajak secara lengkap.

f. Pengusaha Kena Pajak melaporkan faktur pajak tidak sesuai dengan masa penerbitan faktur pajak; atau

g. Pengusaha Kena Pajak yang gagal berproduksi dan telah diberikan pengembalian Pajak Masukan sebagaimana dimaksud dalam Pasal 9 ayat (6a) UU PPN.

\section{Penerapan pelanggaran administrasi}

Penerapan pelanggaran administrasi yang diatur dalam UU KUP berfungsi sebagai penegakkan hukum dalam ranah pemeriksaan pajak yang bersifat administratif maupun penampung semua tindak kejahatan namun secara diskresi dikategorikan sebagai administratif sehingga terjadi ambiguitas dalam penerapannya.

Pelanggaran administrasi yang dilakukan oleh WP telah diatur dalam Pasal 13 UU KUP seharusnya mempertimbangkan 3 (tiga) pendekatan sebagai berikut:

a. Menjadi sarana penegakkan hukum terhadap pelanggaran administrasi pidana pertama kali;

b. Menjadi sarana untuk menegakkan pelanggaran administrasi untuk kesalahan WP yang tidak mendaftarkan diri untuk diberikan NPWP atau dikukuhkan PKP karena sarana administrasi awal WP untuk membayar pajak dan untuk memberikan efek jera maka 
kewajiban perpajakannya dapat dikenakan terhitung sejak seharusnya memenuhi syarat menjadi WP atau PKP dengan memperhatikan daluwarsa pajak dan untuk itu perlu menghapus dari tindak pidana pada Pasal 39 ayat (1) huruf a UU KUP;

Pertimbangan pelanggaran pidana yang termasuk pelanggaran administrasi sesuai kewenangan melalui diskresi. Adapun contoh-contoh kesalahannya adalah tidak lengkap melampirkan persyaratan administratif, tidak/kurang memungut/memotong pajak, transfer pricing, kesalahan penerapan ketentuan, kesalahan penafsiran ketentuan, dan tidak/kurang menyetor pajak sendiri.

3. Penerapan pelanggaran administrasi atau tindak pidana

Pengenaan sanksi administrasi atau tindak pidana terjadi pada kesalahan WP sebagai berikut:

a. Untuk kesalahan berikut lebih baik Undang-Undang KUP mengelompokkannya sebagai tindak pidana berat dan sangat berat karena sifat kesalahannya mayor, setara perbuatan pidana penggelapan, pemalsuan, penipuan yang diatur dalam KUHP dan ada niat/karakter jahat serta memberikan dampak negatif yang sangat luas kepada sistem perpajakan di Indonesia sehingga perlu dipidana untuk ditakut-takuti dan diberikan efek jera guna menumbuhkan kesadaran WP. Kesalahan-kesalahan tersebut adalah:

1) Tidak menyetorkan pajak yang telah dipotong/dipungut;

2) Memperlihatkan pembukuan/dokumen palsu;

3) Menyalahgunakan atau menggunakan tanpa hak NPWP atau Pengukuhan PKP;

4) Menolak dilakukan pemeriksaan;

5) Menerbitkan dan/atau menggunakan faktur pajak, bukti pemungutan pajak, bukti pemotongan pajak, dan / atau bukti setoran pajak yang tidak berdasarkan transaksi yang sebenarnya;

6) Menerbitkan faktur pajak tetapi belum dikukuhkan sebagai Pengusaha Kena Pajak.

b. Sedangkan untuk kesalahan berikut seharusnya Undang-Undang KUP mensyaratkan untuk dikategorikan sebagai pelanggaran administrasi terlebih dahulu sebelum kesalahan berikutnya dikategorikan sebagai tindak pidana (pelanggaran administrasi pidana) dengan memperhatikan subtansi perbuatannya, materiil kesalahan, maupun keluasan dampak negatifnya untuk menjawab penjelasan Pasal 12 UU KUP dimana penerbitan suatu surat ketetapan pajak "hanya terbatas pada Wajib Pajak tertentu". Dengan demikian nantinya ada kesalahan WP terkait tidak menyampaikan SPT atau menyampaikan SPT/keterangan tidak benar/tidak lengkap berkali-kali tetap cukup diterbitkan Surat Ketetapan Pajak dan ada yang selanjutnya dikategorikan tindak pidana sehingga memiliki landasan hukum yang jelas. Kesalahan-kesalahan tersebut adalah:

1) Tidak menyampaikan SPT;

2) Menyampaikan SPT/keterangan tidak benar/tidak lengkap atau manipulasi laporan keuangan;

3) Tidak menyelenggarakan / memperlihatkan pembukuan / pencatatan;

4) Tidak menyimpan buku, catatan, atau dokumen yang menjadi dasar pembukuan

Subtansi perbuatannya, materiil kesalahan, maupun dampak negatifnya kesalahan perlu diberikan ketentuan peraturan pelaksanaannya atau delegasi perundang-undangan sesuai pendapat Muchsan dalam bukunya yang berjudul Beberapa Catatan Tentang Hukum Administrasi Negara Dan Peradilan Administrasi Negara Di Indonesia. Hal tersebut untuk 
memberikan parameter sebagai batasan para penegak hukum melakukan diskresi untuk menghindari terjadinya kebebasan intepretasi/penafsiran hukum seperti penafsiran gramatikal, sistemik, historis, maupun sosiologis untuk mencari makna-makna yang tertulis dalam undang-undang demi pemenuhan kepentingan umum.

Dengan adanya parameter tersebut dapat dijadikan sebagai petunjuk memberikan suatu pilihan keputusan dan/atau tindakan kepada para penegak hukum untuk menetapkan sanksi administrasi atau pidana. Ketiadaan atau ketidakjelasan peraturan perundangundangan memang tidak menghalangi pejabat pemerintahan yang berwenang untuk menetapkan dan/atau melakukan keputusan dan/atau tindakan sepanjang memberikan kemanfaatan umum dan sesuai dengan Asas umum pemerintahan yang baik sebagaiamana diatur dalam Pasal 9 ayat (4) Undang-Undang Nomor 30 Tahun 2014.

\section{B.Penerapan Ultimum Remedium Tindak Pidana Perpajakan dalam Undang-Undang KUP.}

Melanjutkan penjelasan sebelumnya, lembaga legislatif telah mengiringi langkahlangkah penegakkan hukum dari himbauan, pemeriksaan administrasi, pemeriksaan bukti permulaan, dan penyidikan dalam Undang-Undang KUP dengan langkah-langkah penyelesaian sesuai Sila Ke-4 Pancasila secara musyawarah mufakat di setiap tahapannya yaitu pada Bab III tentang Penetapan dan Ketetapan dalam Pasal 8 dan Pasal 13A dan Bab VIII tentang Ketentuan Pidana dalam Pasal 44B UU KUP. Namun yang perlu dipastikan adalah pada setiap tingkatan tersebut WP telah diinformasikan haknya serta sanksi administrasinya dan dipastikan WP tidak mau menggunakan haknya apabila ingin dilakukan penegakkan hukum hingga ke sanksi pidana sebagaimana telah diatur dalam ketentuan Undang-Undang KUP yaitu:

a. Lapor SPT Normal sesuai Pasal 12 UU KUP;

b. Membetulkan sendiri SPT sesuai Pasal 8 ayat (1) UU KUP;

c. Mengungkapkan ketidakbenaran pengisian SPT sesuai Pasal 8 ayat (1) UU KUP;

d. Mengungkapkan ketidakbenaran perbuatan sesuai Pasal 8 ayat (3) UU KUP,

e. Permintaan penghentian penyidikan sesuai Pasal 44B UU KUP.

Penegakkan hukum pidana pada prinsipnya dikembalikan pada tujuan pemidaan itu sendiri. Fungsi dan tujuan dari sanksi pidana pada hakekatnya adalah memiliki 2 (dua) fungsi yaitu menakut-nakuti WP dan/atau memberikan efek jera sebagai sarana untuk membantu menegakkan atau melaksanakan hukum administrasi. Sedangkan dalam Undang-Undang KUP tujuan pemidanaan adalah untuk tumbuhnya kesadaran Wajib Pajak untuk mematuhi kewajiban perpajakan serta efek jera (deterrent effect) dalam pelaksanannya. Hal ini disebabkan karena fungsi pajak paling utama adalah untuk penerimaan negara (fungsi budgeter) di bandingkan dengan fungsi yang lainnya seperti mengatur, stabilitas, dan redistribusi pendapatan. Sebagai konsekuensi hukum pajak merupakan hukum pidana administratif maka penegakkan hukum pidana bersifat subsidiaritas manakala penegakkan hukum administrasi sudah tidak efektif pelaksanaannya barulah dioperasionalkan penegakkan hukum pidana (ultimum remedium). Tujuan hukum yang ingin dicapai dalam penerapan asas ultimum remedium adalah kemanfaatan dan keadilan atau efisiensi dan equality.

Asas ultimum remedium dalam ketentuan perpajakan secara eksplisit hanya ditemukan dalam peraturan pelakasanaan Undang-Undang KUP yaitu Keputusan Dirjen Pajak Nomor KEP-272/PJ/2002 tanggal 17 Mei 2002 tentang Petunjuk Pelaksanaan Pengamatan, Pemeriksaan Bukti Permulaan, dan Penyidikan Tindak Pidana Di Bidang Perpajakan yang menyebutkan bahwa pada dasarnya kegiatan penyidikan tindak pidana di 
bidang perpajakan adalah upaya paling akhir (ultimatum remedium) dalam usaha penegakkan ketentuan perundang-undangan perpajakan yang berlaku setelah upaya lain yang telah dilaksanakan sebelumnya. Selanjutnya sejak Undang-Undang Nomor 27 Tahun 2008 yang berlaku 1 Januari 2008 baru mengenalkan asas ultimum remedium yang disebutkan secara eksplisit pada memori penjelasan Pasal 13A UU KUP yang berbunyi pengenaan sanksi pidana merupakan upaya terakhir untuk meningkatkan kepatuhan Wajib Pajak. Namun, bagi Wajib Pajak yang melanggar pertama kali alpa terkait dengan penyampaian SPT tidak dikenai sanksi pidana, tetapi dikenai sanksi administrasi. Namun hal ini menyebabkan timbulnya permasalahan baru karena apabila dilakukan penafasiran secara a contrario maka dianggap langkah-langkah penegakkan hukum yang lain tidak memiliki asas ultimum remedium.

Pengaturan model ultimum remedium tidak diatur dalam satu bab atau pasal saja sehingga harus dilakukan penafsiran sistematis dalam menafsirkan suatu ketentuan katakata dalam suatu peraturan dalam hubungannya dengan kalimat yang bersangkutan serta seluruh pasal dalam UU KUP harus dianggap sebagai suatu kesatuan sistem integral terkait, terpadu, dan saling dukung. Hal inilah yang menyebabkan para penegak hukum memiliki pemahaman dan tafsir asas ultimum remedium yang tidak seragam mengingat undangundang tidak mengatur secara eksplisit dan ketentuan dalam undang-undang saling beririsan dan saling terkait satu sama lain. Contoh kasus adalah pidana perpajakan yang diputus oleh hakim di Pengadilan Negeri Bukit Tinggi Nomor 103/Pid.Sus/2015/PN Bkt yang memutuskan lepas karena pertimbangan hakim menganggap WP memang terbukti secara sah dan meyakinkan melakukan tindak pidana tidak melaporkan SPT dengan benar namun upaya penegakkan hukum secara administrasi atau upaya ultimum remedium belum maksimal diupayakan. Namun berbeda dengan putusan hakim di Pengadilan Negeri Kendal Nomor 66/Pid.B/2012/PN.Kdl, Pengadilan Negeri Yogyakarta Nomor 124/Pid.Sus/2013/PN.YK, Pengadilan Negeri Bekasi Nomor 44/Pid.Sus/2016PN.Bks, Putusan Mahkamah Agung Nomor 2239K/PID.SUS/2012, dan Putusan Mahkamah Agung Nomor 898 K/PID.SUS/2014 yang kelimanya memvonis bersalah semua WP dengan sanksi pidana penjara dan pidana administrasi karena terbukti secara sah dan meyakinkan telah melakukan tindak pidana perpajakan yaitu tidak lapor SPT dengan benar. Tetapi jika penulis perhatikan dari pertimbangan hukumnya pada prinsipnya para hakim setuju bahwa hukum pidana perpajakan menganut asas ultimum remedium. Namun dalam memaknai penerapan memulai dari tahapan yang mana terlihat antara hakim satu dengan yang lain tidak memiliki pemahaman yang sama. Ada yang berpendapat penerapan asas ultimum remedium dimulai dengan sejak tindakan adminstrasi sudah diterapkan terlebih dahulu secara sekuensial dari Surat Teguran, Himbauan, pemeriksaan administrasi.

Menurut penulis asas ultimum remedium di dalam Undang-Undang KUP memiliki 2 (dua) model :

1. Diterbitkan penegakkan hukum administratif terlebih dahulu

Sanksi pidana merupakan langkah terakhir yang ditempuh penegak hukum apabila penggunaan sarana hukum administratif tidak efektif lagi dan harus dilakukan tindakan administratif secara sekuensial (berurutaan). Ketentuan tindakan adminsitratif telah diatur dalam beberapa pasal dalam Undang-Undang KUP yaitu Pasal 3 ayat (5a), Pasal 8 ayat (1), Pasal 8 ayat (4), Pasal 13 ayat (5).

Sejalan dengan pengelompokkan pelanggaran administrasi pidana dimana WP yang menurut diskresi penegak umum sesuai dengan kewenangan yang diberikan undangundang maka berdasarkan asas ultimum remedium penegak hukum secara official assessment terlebih dahulu melakukan tindakan administratif berupa Surat Teguran, Surat Himbauan, kesempatan pengungkapan ketidakbenaran pengisian SPT, dan 
berakhir terbitnya Surat Ketetapan Pajak untuk pertama kalinya. Dan selanjutnya apabila sesuai diskresi penegak hukum, dinilai WP masih melakukan pelanggaran setelah pertama kali maka Wajib Pajak masih dimungkinkan diterbitkan Surat Ketetapan Pajak dan tetap diberikan kesempatan haknya untuk memanfaatkan exit clause. Namun hal ini hanya berlaku untuk WP yang termasuk kelompok pelanggaran administrasi pidana seperti terkait dengan SPT (lampiran kelengkapan) dan pembukuan/pencatatan.

2. Kesempatan Exit Clause atau pintu terakhir

Ultimum remedium dapat diberikan oleh penegak hukum setelah diberikan peluang penyelesaian hukum lewat cara hukum lain seperti kekeluargaan, negosiasi, mediasi, perdata atau hukum administrasi ditempuh terlebih dahulu.

Ketentuan exit clause telah disediakan oleh Undang-Undang KUP Nomor 6 Tahun 1983 yang berlaku sejak 1 Januari 1984 yang diatur dalam Pasal 8 ayat (3) dan Pasal 44B UU KUP. Dimana Wajib Pajak yang melakukan tindak pidana perpajakan baik pidana ringan, berat, dan sangat berat masih diberikan kesempatan terakhir untuk memanfaat exit clause melalui mekanisme self assessment ditambah sanksi administrasi sebelum dilanjutkan proses pemidanaannya sepanjang perkara pidana tersebut belum dilimpahkan ke pengadilan.

Pasal 8 ayat (3) KUP Walaupun telah dilakukan tindakan pemeriksaan, tetapi belum dilakukan tindakan penyidikan mengenai adanya ketidakbenaran yang dilakukan Wajib Pajak yang alpa terkait dengan SPT (melampirkan keterangan), terhadap ketidakbenaran perbuatan Wajib Pajak tersebut tidak akan dilakukan penyidikan, apabila Wajib Pajak dengan kemauan sendiri mengungkapkan ketidakbenaran perbuatannya tersebut dengan disertai pelunasan kekurangan pembayaran jumlah pajak yang sebenarnya terutang beserta sanksi administrasi berupa denda sebesar $150 \%$ (seratus lima puluh persen) dari jumlah pajak yang kurang dibayar. Namun ketentuan yang berlaku hanya untuk kealpaan SPT (keterangan) tersebut diperluas dengan Pasal 23 ayat (3) Peraturan Nomor 239/PMK.03/2014 tentang Tata Cara Pemeriksaan Bukti Permulaan Tindak Pidana di Bidang Perpajakan mengatur bahwa, termasuk Tindak Pidana di Bidang Perpajakan yang dapat dilakukan pengungkapan ketidakbenaran perbuatan kealpaan terkait SPT (keterangan yaitu Tindak Pidana di Bidang Perpajakan yang berkaitan dan berbarengan dengan tindak pidana tidak menyampaikan Surat Pemberitahuan atau menyampaikan Surat Pemberitahuan yang isinya tidak benar atau tidak lengkap, atau melampirkan keterangan yang isinya tidak benar, sehingga dapat menimbulkan kerugian pada pendapatan negara. Hal ini yang melandasi tindak pidana perpajakan yang diatur dalam Pasal 39 dan39A KUP juga diberikan exit clause yang sama dengan Pasal 38 KUP. Untuk selanjutnya diusulkan diatur exit clause berlaku otomotis untuk Pasal 38, 39, dan 39A KUP dalam Pasal 8 ayat (3) KUP.

\section{PENUTUP}

\section{A. Kesimpulan}

Rumusan saksi administrasi dan sanksi pidana sebagai dasar penerapan asas ultimum remedium dalam tindak pidana perpajakan sesuai Undang-Undang KUP belum berfungsi sesuai dengan tujuannya yaitu menumbuhkan kesadaran Wajib Pajak untuk mematuhi kewajiban perpajakan karena proses penegakkan hukum pada tahap formulasi (kebijakan legislatif) belum memiliki kepastian hukum yang berkeadilan sehingga terdapat 
kebebasan interpretasi/penafsiran para penegak hukum dengan diskresi bebas (tidak terikat) yang berdampak pada tahap aplikasi (yudikatif) dan tahap eksekusi.

Penerapan asas ultimum remedium tidak diatur dalam satu bab atau pasal di Undang-Undang KUP sehingga harus dilakukan penafsiran sistematis dalam menafsirkan suatu ketentuan kata-kata dalam suatu peraturan dalam hubungannya dengan kalimat yang bersangkutan serta seluruh pasal dalam UU KUP harus dianggap sebagai suatu kesatuan sistem integral terkait, terpadu, dan saling dukung agar tidak menimbulkan perbedaan persepsi dan pemahaman dalam penerapannya.

\section{B. Saran}

Dari pembahasan dan kesimpulan dapat penulis sarankan sebagai berikut:

1. Perlu dilakukan reformulasi terkait dengan pengelompokkan kesalahan WP yang termasuk pelanggaran secara administrasi dan pidana sehingga lebih jelas dan tegas serta memerlukan petunjuk pelaksanaan untuk pelanggaran yang termasuk keduanya yaitu administrasi pidana sebagai pedoman bagi penegak hukum untuk mengurangi kebebasan interpretasi/penafsiran dengan diskresi terikat agara supaya dapat memenuhi asas yuridiksitas, legalitas, dan asas umum pemerintahan yang baik.

2. Penerapan asas ultimum remedium perlu ditafsirkan secara sistematis dengan 2 (dua) model yaitu model ultimum remedium secara sekuensial untuk pelanggaran secara administratif pidana serta model exit clause untuk pelanggaran secara pidana.

\section{DAFTAR PUSTAKA}

\section{Buku}

Adrianto Dwi Nugroho, Hukum Pidana Pajak Indonesia, Citra Aditya Bakti, Bandung, 2010

Henry D.P. Sinaga dan Benny R.P. Sinaga, Rekonstruksi Modep-Model Pertanggung jawaban di Bidang Perpajakan dan Kepabeanan, Kanisius, Jogjakarta, 2018

Mohammad Daud Ali, Hukum Islam, Pengantar Ilmu Hukum dan Tata Hukum Islam di Indonesia, Raja Grafindo, Jakarta, 2001

P.A.F. Lamintang, Dasar-Dasar Hukum Pidana di Indonesia, Citra Aditya Bakti, Bandung, 1997

Satjipto Rahardjo, Ilmu Hukum, Alumni, Bandung, 1985

Simanjuntak dan Mukhlis Dimensi Ekonomi Perpajakan dalam Pembangunan Ekonomi, Raih Asa Sukses (RAS), Jakarta, 2012

Simon Nahak, Hukum Pidana Perpajakan, Setara Press, Malang, 2014

Soedjono Dirdjosisworo, Pengantar Ilmu Hukum, Jakarta, Raja Grafindo Persada, 2008

Susi Zulvina, Pengantar Hukum Pajak, Jakarta, STAN, 2011

Waluyo, Perpajakan Indonesia, Salemba Empat, Jakarta, 2010

Zaeni Asyhadie dan Arief Rahman, Pengantar Ilmu Hukum, Jakarta, Raja Grafindo Persada, 2013

\section{Peraturan Perundang-Undangan dan Peraturan Pelaksanaan}

Kitab Undang-Undang Hukum Pidana.

Undang-Undang Nomor 6 Tahun 1983 tentang Ketentuan Umum dan Tata Cara Perpajakan sebagaimana telah beberapa kali diubah terakhir dengan UndangUndang Nomor 16 Tahun 2009 


\section{Sumber Lain}

Eddy O.S Hiariej, "Penegakkan Hukum Pidana Pajak:Ultimum Remedium ataukah Primum Remedium?", Seminar Ultimum Remedium : Dari Sisi Hukum Pidana dan Hukum Administrasi Negara, Jogjakarta, 2018

Fadhil, "Penafsiran Hukum Pajak", http://aspirasipajak.blogspot.com, diakses 30 Juni 2019

Gunadi, "Konsep Daluwarsa dan Ultimum Remedium dalam UU KUP”, Seminar Ultimum Remedium: Dari Sisi Hukum Pidana dan Hukum Administrasi Negara, Jogjakarta, 2018

Mardjono Reksodiputro, "Kriteria Penentuan Berat -Ringannya Perumusan Ancaman Pidana", Focus Group Discussion (FGD) Politik Perumusan Ancaman Pidana dalam Undang-Undang di Luar KUHP yang diselenggarakan oleh Badan Pembinaan Hukum Nasional Kementerian Hukum dan HAM, Jakarta, 2010

Muchsan, Beberapa Catatan Tentang Hukum Administrasi Negara Dan Peradilan Administrasi Negara Di Indonesia, Liberty, Yogyakarta, 1981

Soerjono Soekanto, "Faktor-Faktor yang Mempengaruhi Penegakkan Hukum", Pidato Pengukuhan dalam Jabatan Guru Besar Tetap pada Fakultas Hukum Universitas Indonesia, Jakarta, 1983

Chandra Khoirunnas, "Penerapan Primum Remedium terhadap Hukuman Mati Bagi Terpidana Narkoba", http://ckhoirunnas.blogspot.co.id, diakses 31 Desember 2016 